\title{
Bleaching of Fabrics Produced from Casein Fibers
}

\author{
H. Gökcin Sevgisunar ${ }^{1}$, Arzu Yavas ${ }^{2}$ \\ ${ }^{1}$ Adin Oto Donanım Sanayi ve Ticaret A.Ş. Gönen/ Balıkesir, Turkey \\ ${ }^{2}$ Pamukkale University / Engineering Faculty, Textile Engineering Department / Denizli, 20160, Turkey
}

Corresponding Author: Arzu Yavas, aozerdem@pau.edu.tr

\begin{abstract}
The $\mathrm{pH}$ of milk fibers, which can be obtained even from the protein of sour milk, is compatible with the human body. Besides being ecological, they have biodegradable properties. In this paper the influence of different bleaching conditions with hydrogen peroxide and thioureadioxide (TUDO) on the whiteness of casein fiber fabric was investigated. Bleaching was carried out both conventionally and with microwave energy. Whiteness, bursting strength, hydrophilicity, and chemical oxygen demand (COD) values were determined and compared. The structures of the untreated and treated casein fabrics were investigated with Fourier transform infrared spectroscopy (FTIR) and scanning electron microscopy (SEM). The effect of bleaching on the structure of casein fabric was investigated with scanning electron microscopy (SEM). The loss of strength in milk fiber based fabrics which have been bleached with peroxide in acidic medium is less than the loss in bleaching in basic medium. Microwave energy can produce whiteness levels obtained by conventional method in much shorter periods. Strength losses are also less. The air permeability test results show that the air permeability of casein fiber based fabric samples decreases with increasing processing temperature and processing time. Careful selection of process temperature and duration is important for milk fibers as well as for wool fibers. When working with milk fibers it is recommended to test the dimension peroxide bleaching change according to the process conditions.
\end{abstract}

\section{ARTICLE HISTORY}

Received: 28.11 .2019

Accepted: 12.02.2020

\section{KEYWORDS}

casein fabric, milk fiber, peroxide bleaching, thioureadioxide, microwave

\section{INTRODUCTION}

The raw materials utilized for the preperation of regenerated protein fibers might be milk, soybean, peanut and zein [1]. Fast development of cheaper synthetic fibres with outstanding mechanical characteristics in the early sixties had effect on the commercial manufacture of regenerated protein fibres that was totally discontinued in the middle of the 1960s [2]. Casein fiber is one of the regenareted protein fibers of milk protein origin. Lanital is developed as the first commercial casein fiber [3]. Various casein fiber brands such as Aralac, Caslen (USA), Lactofil, Casolana (Netherlands), Cargan (Belgium), Tiolan, Tiocell (Germany), Silkool (Japan), Fibrolane (Great Britain) have been manufactured in various countries [4-6]. The original Lanital (France) has been improved and produced under various trade names such as Merinova (Italy) and Wipolan (Poland) [7].
Fibrolane (Great Britain) and Merinova (Italy) are formed by dissolving casein in sodium hydroxide and then by extrusion into an acid / salt bath. The fibres formed in this way is stretched as tow and partially stabilised by formaldehyde treatment [1]. The process requires a lot of water [8]. New methods have been found in recent years to produce these fibers in a more environmentally friendly manner and a new process is developed without the use of formaldehyde [8]. A newly developed process for the production of casein fibers without formaldehyde is described in a recent patent [9], but these fibers are not yet available commercially. In the study carried out by Bier et al., casein fibers were produced according to two different approaches, using water and heat or sodium hydroxide. In both ways, relatively flexible fibers and textile coatings were gained [10]. 
Casein fibers have a certain similarity to sheep's wool. It is a phospho-protein built up from a number of amino acids [11]. The general properties of regenerated protein fibres include the wool like attributes of resilience, warmth and soft handle. The strength of regenerated protein fibers is lower than of wool fibres. Casein fibers have no cystine linkage, which leads to a more open structure [1].

Milk protein fiber is comfortable and has excellent water transportation and air-permeability [12]. These biodegradable and renewable fibers have also better resistance to attack by microorganisus such as bacteria and fungus. Besides its antimicrobial activity casein fibers is healtier [12]. Their smooth structure makes them feel similar to silk, and the high moisture absorption lets the fibers swell and makes them softer and thus especially attractive for people with skin diseases. Additionally, they can easily be dyed and age only slowly [10]. Casein can also be extracted from "non-food milk", i.e. waste which cannot be used in the food industry. For this reason casein fiber would be a sustainable alternative to other natural fibers. The usage of casein fiber is expected to increase in the near future due to its eco-friendly footprints [13].

In the study carried out by Lei et al. wearabilities, tensile property, appearance property and abrasive resistance of milk protein fiber plain knitted fabric were tested [14]. According to the research casein fiber can be regarded as an ideal fiber fabric used as underwear in spring, autum and winter [14]. In the study carried out by Rathinamoorthy thermal comfort and moisture management characteristics of knitted casein fabric have been evaluated and compared with cotton fabric for the application of undergarment [15].

First concepts of MW use for textile finishing processes emerged in the 1970s when cellulosic fabrics were treated with Durable Press finishing agents and healed in a microwave oven [16]. Textile finishing using microwave heating has been reported by several authors [17, 18, 19, $20,21,22,23,24,25,26,27,28]$. Microwave heating has proven to be more rapid, uniform and efficient than other heating methods [29]. Furthermore it is a clean and environmentally friendly technology.

In the study carried out by El-Kheir et al., microwave irradiation was used to reduce consumption of energy and time during bleaching of wool fabrics with hydrogen peroxide [30].
In this study, bleaching process of fabrics produced from $100 \%$ casein fibers was investigated. Hydrogen peroxide and thioureadioxide (TUDO) were used for bleaching. Bleaching was carried out using conventional method and microwave energy. The whiteness / yellowness, strength and hydrophilicity values of the treated samples were determined and the results were compared.

\section{MATERIAL AND METHOD}

\subsection{Material}

$100 \%$ casein milk fiber yarn $(32 / 1 \mathrm{Ne})$ single jersey knitted fabric $(140 \mathrm{~g} / \mathrm{m} 2)$ is used in this study. $100 \%$ casein milk fiber yarn is obtained from China. The whiteness degree of greige un-treated casein milk fiber fabric was 56.91 Stensby.

\subsection{Method}

Scouring process, at $40^{\circ} \mathrm{C}$ for 10 minutes, was applied to greige milk fabrics twice before any bleaching operations in order to remove any possible impurities which could be found on the surface of the fabric. Hydrogen peroxide bleaching operations were applied to casein (milk) fabrics using Ataç Lab Dye HT sample dyeing machine via exhaustion process. In all bleaching processes, $0.5 \mathrm{~g} / \mathrm{l}$ nonionic wetting agent was added to the bleaching bath (Table 1).

Peroxide bleaching of wool under mild acidic conditions ( $\mathrm{pH}$ 5-6) can also be carried out using a peracid activator such as Prestogen W (BASF). As wool sustains some damage in the presence of alkali, this method is useful for bleaching delicate fabrics. In the bleaching processes of milk fibers, as in wool fiber, bleaching in acidic medium was carried out microwave energy assisted reductive and hydrogen peroxide bleaching processes were carried out using Arçelik MD 565 model microwave oven (900 watt) via exhaustion process. Casein milk fiber fabrics were bleached with microwave energy assistance for 1, 3 and 5 minutes. Bleaching liquor are prepared at room temperature and poured into closed glass container. After 1minute microwave energy application, bleaching liquor was started to boil and after 5 minutes of application all liquor was evoparated.

Table 1. Hydrogen peroxide used for casein fiber bleaching and their processing detail

\begin{tabular}{llll}
\hline \multicolumn{2}{l}{ Peroxide bleaching under alkaline conditions } & \multicolumn{2}{l}{ Peroxide bleaching under acidic conditions } \\
\hline Hydrogen peroxide $(35 \%)$ & $10,15,30,45,65 \mathrm{ml} / 1$ & Hydrogen peroxide $(35 \%)$ & $10,30,45,65,90,120 \mathrm{ml} / 1$ \\
Temperature $\left({ }^{\circ} \mathrm{C}\right)$ & $50,60,70,80,90^{\circ} \mathrm{C}$ & Temperature $\left({ }^{\circ} \mathrm{C}\right)$ & $60,80,90^{\circ} \mathrm{C}$ \\
Time (minutes) & $45,60,90,120$ & Time (minutes) & 60 \\
$\mathrm{pH}$ & $\mathrm{pH} 9$ & $\mathrm{pH}$ & $\mathrm{pH} 5$ \\
liquor ratio & $1: 40$ & liquor ratio & $1: 40$ \\
nonionic wetting agent & $0.5 \mathrm{~g} / \mathrm{l}$ & nonionic wetting agent & $0.5 \mathrm{~g} / \mathrm{l}$ \\
stabilizer & $1 \mathrm{~g} / 1$ & Prestogen $\mathrm{W}$ & $2,6,9,13,18,24 \mathrm{~g} / 1$ \\
\hline
\end{tabular}




\subsection{Analysis and Testing}

Following various abovementioned bleaching treatments, the whiteness (Stensby value) and yellowness (E313 YI) of the casein fiber fabrics were determined using a Datacolor 600 spectrophotometer. The hydrophilicity property of bleached and untreated control casein milk fiber fabrics was measured as the time, in seconds, of water absorption of the specimen according to TS 866 standard. Moreover, bursting strength properties of bleached milk knitted fabric was carried out in accordance with ISO 13938-2, using an SDL Atlas M229P bursting tester, under the standard laboratory conditions ( $20 \pm 2 \mathrm{C} ; 65 \pm 2 \%$ relative humidity).

Test fabrics were tested for their air permeability on FX 3300 air permeability tester (Textest A.G, Switzerland) according to EN ISO 9237 standard.

The surface morphologies of bleached casein fabrics were examined by using scanning electron microscopy (SEM, Zeiss EVO 40). Before the test, the samples were coated with a thin gold film layer to increase the conductivity.

The infrared analysis was performed using a Infrared Spectrometer (FT-IR) with diamond universal ATR accessory in ATR mode. Waste bleaching floats were measured according to closed reflux method for Chemical Oxygen Demand (COD). The conventional and microwave assisted bleaching of casein milk fiber fabrics was compared according to the test results.

\section{RESULTS AND DISCUSSION}

\subsection{Conventional Bleaching of Casein Fabric}

\section{Effect of pH}

According to bleaching results to determine optimum $\mathrm{pH}$ value, peroxide bleaching at $\mathrm{pH} 5$ and $\mathrm{pH} 9$ gave the highest whiteness values. Bleaching at $\mathrm{pH} 11$ causes the whiteness of the fabric samples produced from milk fiber to decrease and yellowing of the samples (Table 2). As it is known that the liberation of $\mathrm{HO}^{2-}$ ion at higher $\mathrm{pH}$ (above 10.8 ) is so quick that it becomes unstable with the formation of oxygen gas which possesses no bleaching character. At higher $\mathrm{pH}$ conditions, hydrogen peroxide is not stable and henceforth a stabiliser is often added in the bleaching bath [1].

\section{Effect of temperature}

Bleaching process was applied to milk fibers at $50^{\circ} \mathrm{C}, 60^{\circ} \mathrm{C}$, $70^{\circ} \mathrm{C}, 80^{\circ} \mathrm{C}, 90^{\circ} \mathrm{C}$ at $\mathrm{pH} 9$ where the highest whiteness degree was obtained. Figure 1 shows the measured whiteness and yellowness values of casein fabrics.

It is observed that the whiteness values of the samples increase slightly with increasing peroxide concentration, time and process temperature (Figure 1). However, these increases are not observed at $90^{\circ} \mathrm{C}$. In the bleaching process at $90^{\circ} \mathrm{C}$, whiteness of milk fiber based fabrics remains at low levels even at high hydrogenperoxide concentrations. Process temperature, time and hydrogen peroxide concentration as well as the $\mathrm{pH}$ of the liquor; are the most important factors affecting the bleaching degree and fiber damage. Increasing them more then enough not only increases the damage to the fibers but also reduces the degree of whiteness obtained. The decrease in whiteness at $90^{\circ} \mathrm{C}$ is thought to be due to the high processing temperature. At 5 different $\mathrm{pH}$ and 2 different temperatures, milk fiber-based samples were treated with only water for 60 and 120 minutes without adding any chemicals to the liquor and their whiteness degrees were measured (Figure 2).

According to Figure 2, whiteness value decreases as the temperature and processing time of the milk fibers are increased. Temperature and $\mathrm{pH}$ value selection is important when working with milk fibers. After $\mathrm{pH} 9$, yellowing is observed in the fibers.

In order to observe the effect of heat treatment, milk fibers were exposed to dry heat for 5 minutes at different temperatures. From $90{ }^{\circ} \mathrm{C}$, the degree of whiteness starts to decrease and the yellowing increases with increasing temperature (Figure 3).

Table 2. The effect of $\mathrm{pH}$ on whiteness and yellowness degree

\begin{tabular}{|c|c|c|c|c|c|c|c|c|}
\hline \multicolumn{9}{|c|}{$60^{\circ} \mathrm{C}$} \\
\hline & \multicolumn{2}{|c|}{ pH 5} & \multicolumn{2}{|c|}{ pH 7} & \multicolumn{2}{|c|}{ pH 9} & \multicolumn{2}{|c|}{ pH 11} \\
\hline $\mathbf{H}_{2} \mathbf{O}_{2}$ & 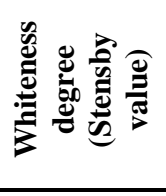 & 总 & 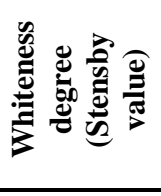 & 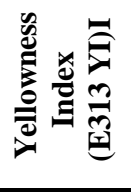 & 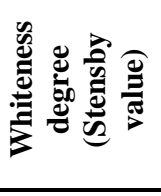 & 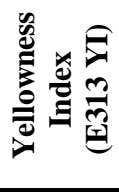 & 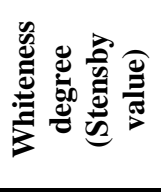 & 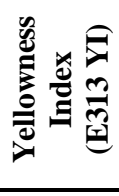 \\
\hline $15 \mathrm{ml} / \mathrm{l}$ & 62,05 & 13,99 & 60,69 & 15,34 & 62,83 & 13,9 & 20,70 & 39,74 \\
\hline $30 \mathrm{ml} / \mathrm{l}$ & 63,30 & 13,78 & 61,57 & 14,91 & 64,83 & 12,71 & 14,02 & 43,61 \\
\hline
\end{tabular}




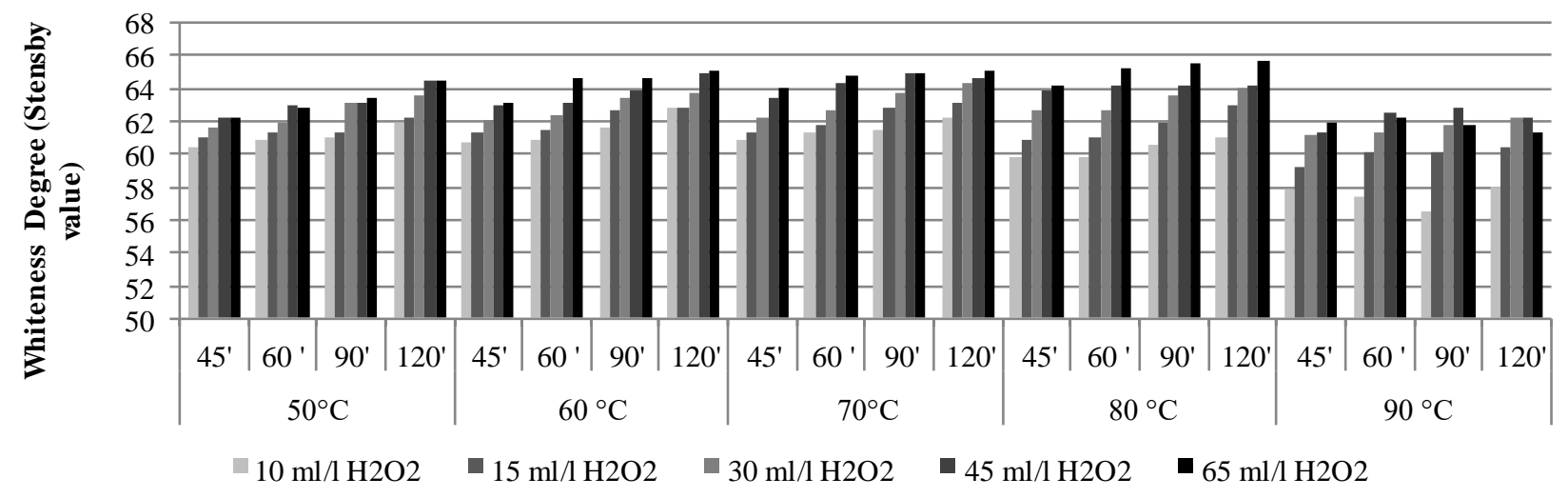

Figure 1. Whiteness and yellowness values of milk fibers after hydrogen peroxide bleaching at $50^{\circ} \mathrm{C}, 60^{\circ} \mathrm{C}, 70{ }^{\circ} \mathrm{C}, 80^{\circ} \mathrm{C}, 90^{\circ} \mathrm{C}$

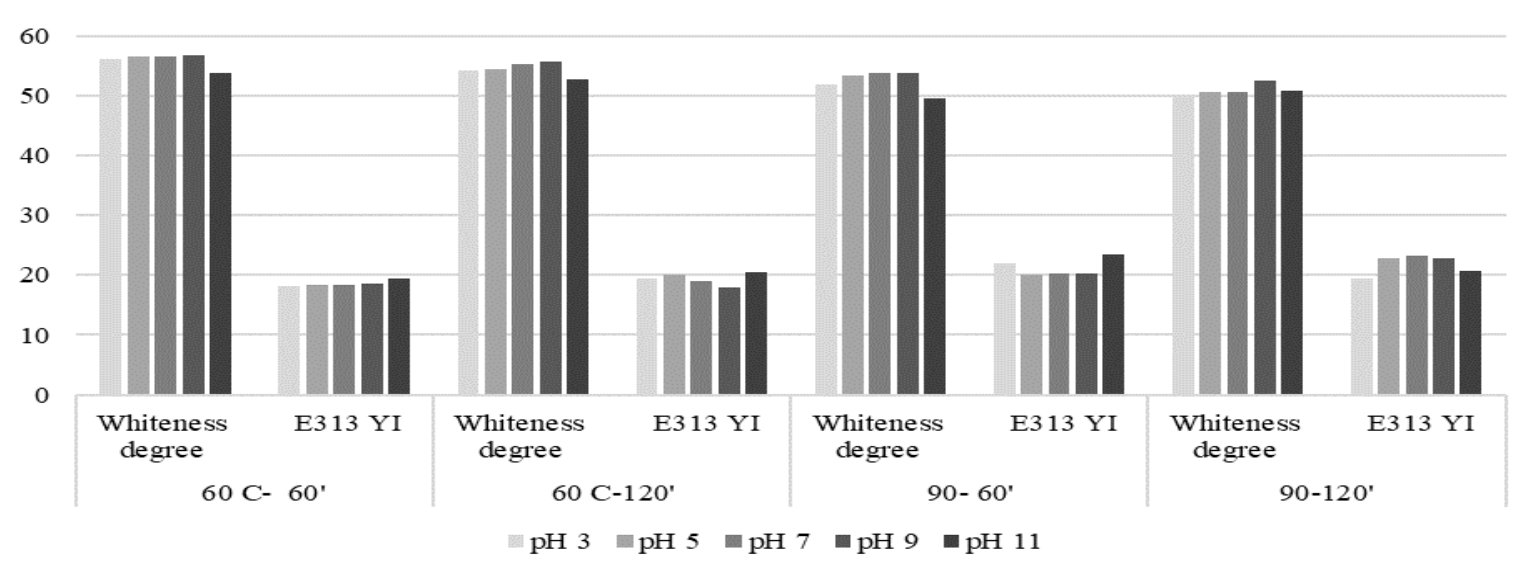

Figure 2. Effect of process temperature on whiteness degree and yellowness index of casein fabric

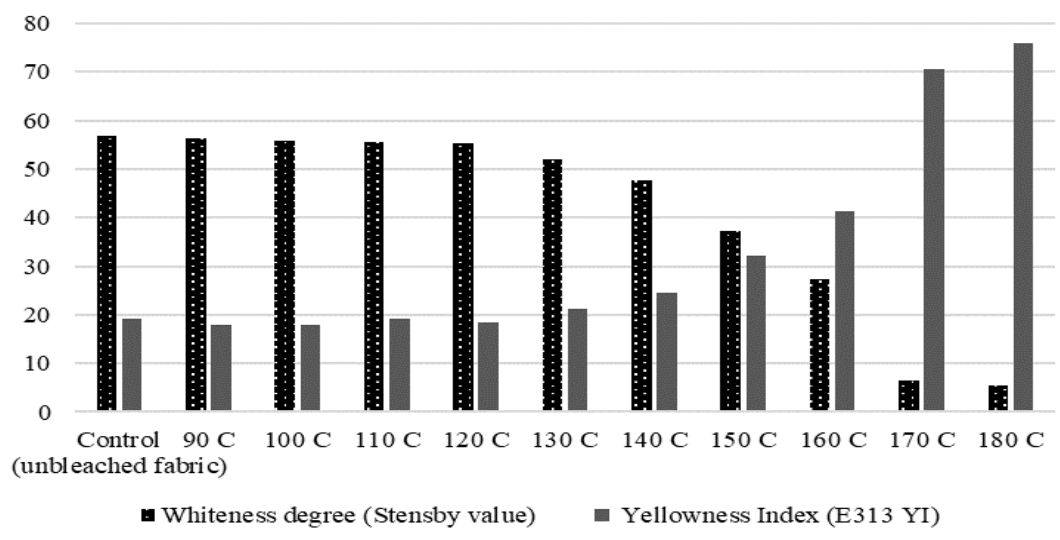

Figure 3. Effect of heat treatment on whiteness degree and yellowness index of casein fabrics

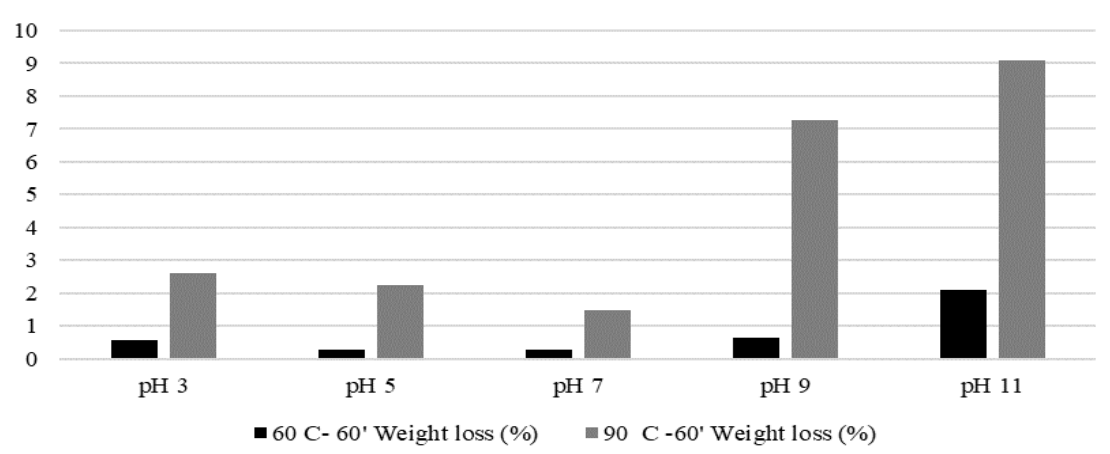

Figure 4. Weight loss of casein fabric at different $\mathrm{pH}$ and temperature 
At pH 3 and pH 9, weight losses in milk fibers increase. The increase in temperature also supports the increase in weight losses (Figure 4). The weight losses at $90^{\circ} \mathrm{C}$ at all $\mathrm{pH}$ values are considerably higher than at $60^{\circ} \mathrm{C}$. Whilst the $\mathrm{pH}$ values where milk fibers had the lowest weight loss were $\mathrm{pH} 5$ and 7 , slightly higher whiteness values were obtained at $\mathrm{pH}$ 9. Therefore, the processing conditions of 120 minutes at $50^{\circ} \mathrm{C}$ (Stensby value 64,44) and 120 minutes at $60^{\circ} \mathrm{C}$ (Stensby value 64,89) with $45 \quad \mathrm{ml} / 1$ hydrogenperoxide at $\mathrm{pH} 9$ are set as reference for subsequent bleaching processes.

\section{Peroxide bleaching under acidic conditions}

During hydrogen peroxide bleaching in acidic medium in presence of Prestogen $\mathrm{W}$, the highest whiteness degree (65.31) could be achieved at a temperature of $60^{\circ} \mathrm{C}$ and 90 $\mathrm{ml} / \mathrm{l}$ hydrogenperoxide concentration. Increasing the process temperature does not improve the whiteness degree. The use of peroxide concentrations greater than $90 \mathrm{ml} / \mathrm{l}$ also does not provide a significant improvement in whiteness (Table 3 ).

The highest whiteness degrees and processing conditions obtained by bleaching milk fibers with hydrogen peroxide $\left(\mathrm{H}_{2} \mathrm{O}_{2}\right)$ are given together in Figure 5 .

Table 3. Whiteness values of mik fibers bleached in acidic medium with hydrogen peroxide $\left(\mathrm{H}_{2} \mathrm{O}_{2}\right)$

\begin{tabular}{|c|c|c|c|c|c|c|}
\hline \multirow[b]{2}{*}{$\begin{array}{l}\mathrm{H}_{2} \mathrm{O}_{2} \\
(\% 35)\end{array}$} & \multicolumn{2}{|c|}{$60^{\circ} \mathrm{C}$} & \multicolumn{2}{|c|}{$80^{\circ} \mathrm{C}$} & \multicolumn{2}{|c|}{$90^{\circ} \mathrm{C}$} \\
\hline & $\begin{array}{c}\text { Whiteness } \\
\text { degree } \\
\text { (Stensby } \\
\text { value) }\end{array}$ & $\begin{array}{c}\text { Yellowness } \\
\text { Index (E313 } \\
\text { YI) }\end{array}$ & $\begin{array}{c}\text { Whiteness } \\
\text { degree } \\
\text { (Stensby } \\
\text { value) }\end{array}$ & $\begin{array}{l}\text { Yellowness } \\
\text { Index } \\
\text { (E313 YI) }\end{array}$ & $\begin{array}{c}\text { Whiteness } \\
\text { degree } \\
\text { (Stensby } \\
\text { value) } \\
\end{array}$ & $\begin{array}{c}\text { Yellowness } \\
\text { Index (E313 } \\
\text { YI) }\end{array}$ \\
\hline $10 \mathrm{ml} / \mathrm{l}$ & 60,74 & 16,78 & 59,67 & 16,81 & 57,82 & 17,27 \\
\hline $30 \mathrm{ml} / \mathrm{l}$ & 62,06 & 15,48 & 62,71 & 14,19 & 61,41 & 14,67 \\
\hline $45 \mathrm{ml} / \mathrm{l}$ & 62,31 & 15,28 & 63,03 & 13,99 & 62,02 & 14,4 \\
\hline $65 \mathrm{ml} / \mathrm{l}$ & 63,07 & 14,72 & 63,56 & 13,6 & 62,75 & 14,04 \\
\hline $90 \mathrm{ml} / \mathrm{l}$ & 65,31 & 12,88 & 64,31 & 12,58 & 63,72 & 13,27 \\
\hline $120 \mathrm{ml} / \mathrm{l}$ & 65,02 & 11,71 & 64,54 & 12,79 & 64 & 12,9 \\
\hline
\end{tabular}

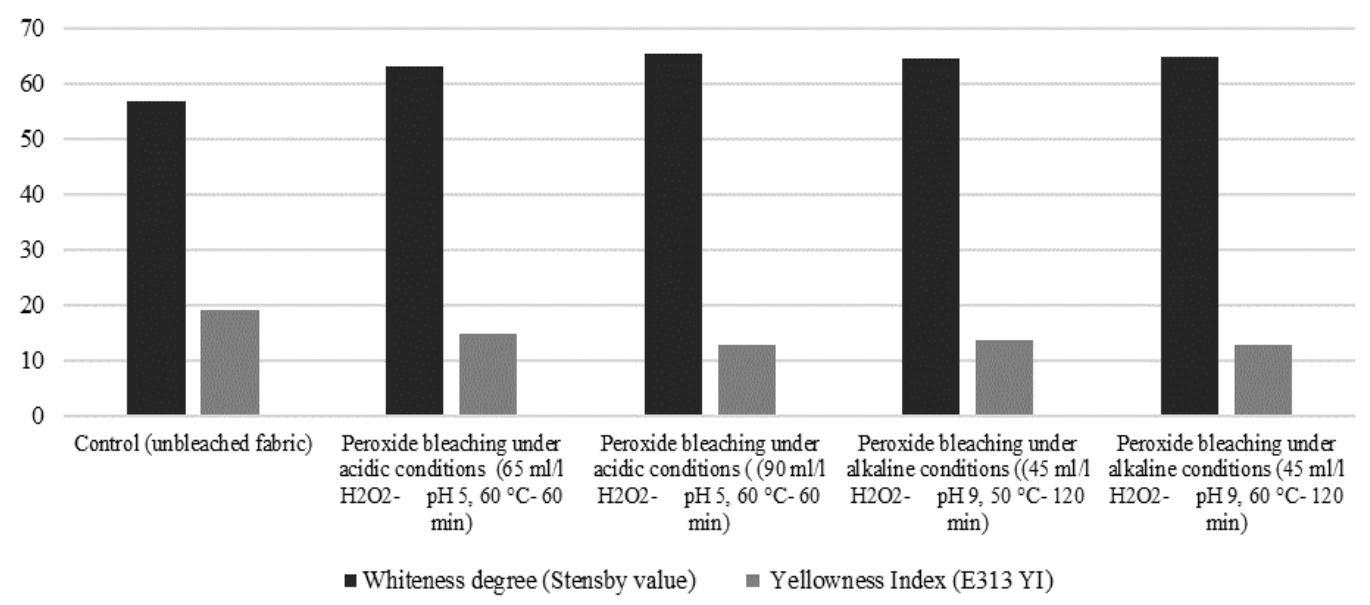

Figure 5. Peroxide bleaching of casein fabric under acidic and alkaline conditions

\section{TUDO bleaching}

Highly reductive sulfinate iedons, which are formed through the hydrolysis of tiouredioxide at high temperatures and neutral and alkali baths into sulfinate anions and urea, provide reductive bleaching (Figure 6) [31].

$$
\begin{aligned}
& \mathrm{H}_{2} \mathrm{~N}-\mathrm{C}(=\mathrm{NH})-\mathrm{SO}_{2} \mathrm{H}+2 \mathrm{OH} \stackrel{\mathrm{pH} 7-8}{\longrightarrow} \underset{2}{\mathrm{H}_{2} \mathrm{~N}-\mathrm{C}(=\mathrm{NH})-\mathrm{OH}+\mathrm{SO}_{2}^{-}} \begin{array}{c}
\text { urea } \\
\text { sulphinate ion }
\end{array} \\
& \mathrm{SO}_{2}^{-}+[\text {chromophore }] \longrightarrow \mathrm{SO}_{4}^{2^{-}}+\text {[reduced chromophore] }
\end{aligned}
$$

Figure 6. TUDO's reaction mechanism [1]
TUDO was used in three different $\mathrm{pH}$ values as 5, 7 and 10 at recommended temperature $90^{\circ} \mathrm{C}$. The whiteness degrees obtained at $\mathrm{pH} 10$ were higher than the whiteness degrees obtained at $\mathrm{pH}$ 7. At a TUDO concentration of $10 \mathrm{~g} / \mathrm{l}$, the whiteness of the milk fibers increased to 67.22 Stensby in 60 minutes at $90^{\circ} \mathrm{C}$ (Figure 7). The rate of degradation of TUDO increases with increasing $\mathrm{pH}$ and temperature and decreases with increasing concentration [1]. If the concentration is further increased, the degree of whiteness decreases. 64 Stensby value could be achieved at $\mathrm{pH} 5$ at high concentrations such as $30 \mathrm{~g} / \mathrm{l}$. The degrees of 
whiteness measured at $\mathrm{pH} 5$ and $\mathrm{pH} 7$ are similar (Figure 7).

Samples of knitted fabrics made of milk fiber were treated at TUDO concentrations of $10 \mathrm{~g} / \mathrm{l}$ and $20 \mathrm{~g} / \mathrm{l}$ where high whiteness was measured at $90^{\circ} \mathrm{C}$ for 30 minutes. According to the results of 60 minutes, the whiteness of the samples was lower (Figure 8).

\section{Two-stage bleaching process}

Wool is often bleached in two-stage process, one being an oxidative step followed by reductive bleach. Hydrogen peroxide is usually used to perform the oxidiative stage, at $\mathrm{pH} 8-10$, followed by a treatment with reduction agents such as thiourea dioxide, hydrosulphite [32]. Two-step bleaching results for casein fibers were also investigated.

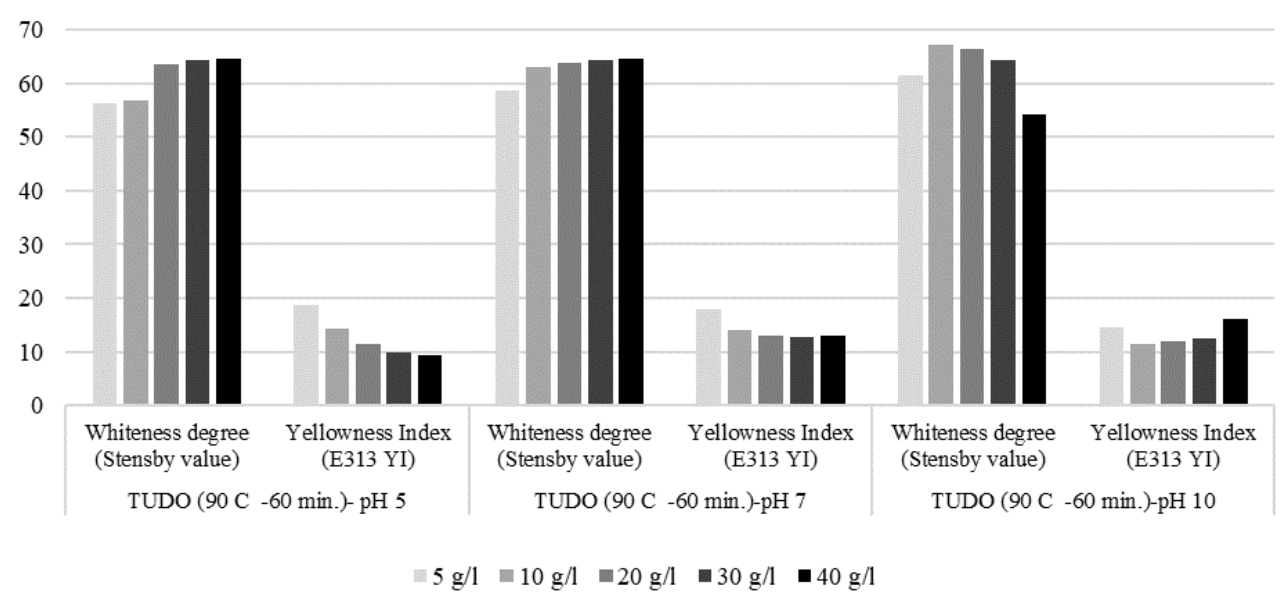

Figure 7. Graph of the whiteness and yellowness values of samples treated with TUDO (thiourea dioxide) at different $\mathrm{pH}$ values

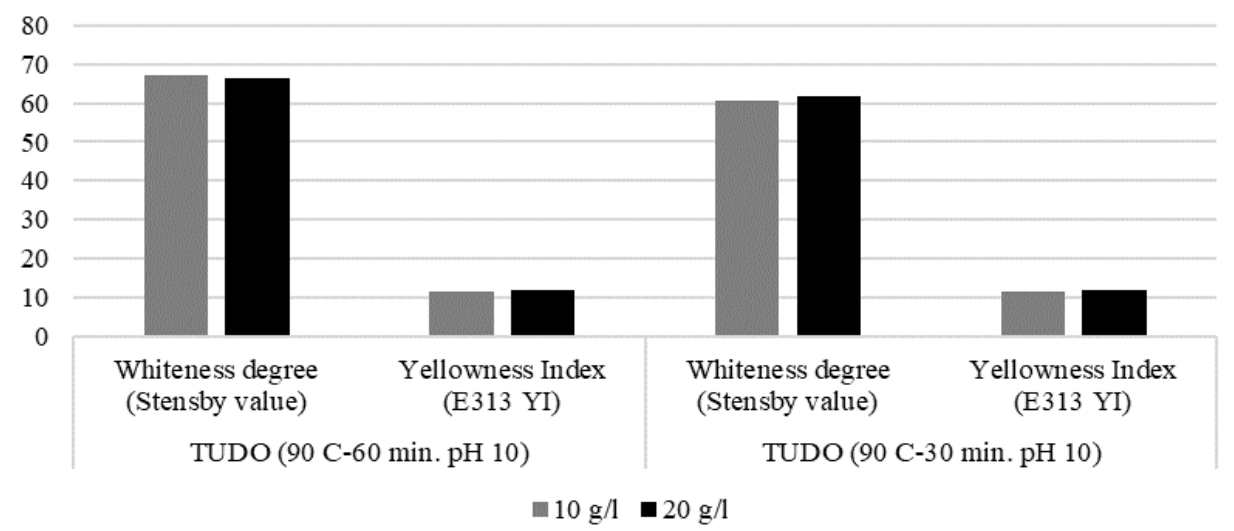

Figure 8. Effect of time on whiteness values of samples treated with TUDO at $90^{\circ} \mathrm{C}$

Table 4. One and two stage bleaching process

\begin{tabular}{|c|c|c|c|}
\hline & & Whiteness degree (Stensby value) & Yellowness Index (E313 YI) \\
\hline & Control (unbleached fabric) & 56,91 & 19,21 \\
\hline \multirow{5}{*}{ 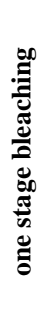 } & $\begin{array}{l}\text { Peroxide bleaching under acidic conditions }(65 \mathrm{ml} / 1 \mathrm{H} 2 \mathrm{O} 2-\mathrm{pH} 5 \text {, } \\
\left.60^{\circ} \mathrm{C}-60 \mathrm{~min}\right)\end{array}$ & 63,07 & 14,72 \\
\hline & $\begin{array}{l}\text { Peroxide bleaching under acidic conditions }(90 \mathrm{ml} / 1 \mathrm{H} 2 \mathrm{O} 2-\mathrm{pH} 5 \text {, } \\
\left.60^{\circ} \mathrm{C}-60 \mathrm{~min}\right)\end{array}$ & 65,31 & 12,88 \\
\hline & $\begin{array}{l}\text { Peroxide bleaching under alkaline conditions }(45 \mathrm{ml} / 1 \mathrm{H} 2 \mathrm{O} 2-\mathrm{pH} 9 \text {, } \\
\left.50{ }^{\circ} \mathrm{C}-120 \mathrm{~min}\right)\end{array}$ & 64,44 & 13,68 \\
\hline & $\begin{array}{l}\text { Peroxide bleaching under alkaline conditions }(45 \mathrm{ml} / 1 \mathrm{H} 2 \mathrm{O} 2-\mathrm{pH} 9 \text {, } \\
\left.60^{\circ} \mathrm{C}-120 \mathrm{~min}\right)\end{array}$ & 64,89 & 12,75 \\
\hline & TUDO bleaching $\left(10 \mathrm{~g} / 1 \mathrm{TUDO}-\mathrm{pH} 10-90^{\circ} \mathrm{C}-60 \mathrm{~min}\right)$ & 67,22 & 11,36 \\
\hline \multirow{4}{*}{ 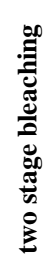 } & $\begin{array}{l}\text { Peroxide bleaching under acidic conditions }(65 \mathrm{ml} / 1 \mathrm{H} 2 \mathrm{O} 2-\mathrm{pH} 5,60 \\
\left.{ }^{\circ} \mathrm{C}-60 \mathrm{~min}\right) \text { after TUDO }\end{array}$ & 65,22 & 11,55 \\
\hline & $\begin{array}{l}\text { Peroxide bleaching under acidic conditions }(90 \mathrm{ml} / 1 \mathrm{H} 2 \mathrm{O} 2-\mathrm{pH} 5 \text {, } \\
\left.60^{\circ} \mathrm{C}-60 \mathrm{~min}\right) \text { after TUDO }\end{array}$ & 67,03 & 10,85 \\
\hline & $\begin{array}{l}\text { Peroxide bleaching under alkaline conditions }(45 \mathrm{ml} / 1 \mathrm{H} 2 \mathrm{O} 2-\mathrm{pH} 9 \text {, } \\
50^{\circ} \mathrm{C}-120 \mathrm{~min} \text { ) after TUDO }\end{array}$ & 66,93 & 10,85 \\
\hline & $\begin{array}{l}\text { Peroxide bleaching under alkaline conditions }(45 \mathrm{ml} / 1 \mathrm{H} 2 \mathrm{O} 2-\mathrm{pH} 9 \text {, } \\
60^{\circ} \mathrm{C}-120 \mathrm{~min} \text { ) after TUDO }\end{array}$ & 67,3 & 10,27 \\
\hline
\end{tabular}


Although two-step bleaching with TUDO after peroxide bleaching increases the whiteness of casein based fabrics compared to single-step bleaching, 67.22 Stensby whiteness can be achieved in one step with TUDO. Given that the two-step process is both costly and time-consuming and does not provide very high whiteness degrees, two-step bleaching for milk fibers may not be the correct mode of operation (Table 4).

\subsection{The Microwave-Assisted Bleaching of Casein Fabric}

As a result of the experiments carried out according to the conventional method, $100 \%$ milk fiber samples were bleached with the help of microwave energy based on the process conditions giving the highest whiteness values. The whiteness, yellowness and hydrophility values of the samples treated with microwave energy in shorter periods were compared with the results obtained in the conventional method.

The whiteness values of the samples bleached by microwave energy do not reach the whiteness values measured in the conventional method. However, it should be noted that the processing time is 5 minutes (Table 5).

As in the classical method, two-step bleaching has also been applied in bleaching processes carried out by using microwave energy. Reduction bleaching followed by peroxide bleaching in acidic media increases the whiteness degree of the samples (67.21 Stensby). With a bleaching time as short as 10 minutes, an increase of whiteness of up to 10 points can be achieved with respect to the whiteness of the unbleached fabric (56.91). The hydrophilicity of the samples improves with respect to the unbleached fabric.
After the bleaching with hydrogen peroxide (61.81 Stensby) in alkal medium by using microwave energy, the whiteness degree (65.97 Stensby) of the sample which was treated with reductive bleaching increased by 3 points. The hydrophilicity values also improved compared to the unbleached fabric (Table 5).

\section{Test and Analysis Results of Casein Fabrics}

\section{Evaluation of bursting strength of casein fabrics}

In addition to achieving a good degree of whiteness during the pre-treatment processes, it is important not to damage the fibers. The bleaching processes can damage the fibers more or less. For this purpose, the strength values of the samples with the best whiteness degree were also investigated. Fabric samples produced from milk fiber suffer more or less chemical damage after bleaching, and the degree of damage to the fibers may vary depending on the bleaching agent and the method applied.

When the bursting strength values of the bleached samples were compared; the loss of strength in the acidic medium peroxide bleaching process is less than the loss in the basic medium bleaching process. In the basic environment, the damage of milk fiber-based samples is slightly higher, despite their similar whiteness values (Table 6). It was determined that the weight loss of the samples treated with water only in the basic medium was higher than the loss of the samples treated with acidic medium.

Table 5. Microwave-assisted bleaching of casein fiber fabric

\begin{tabular}{|c|c|c|c|c|c|c|c|c|}
\hline & & \multicolumn{2}{|c|}{$1 \mathrm{~min}$} & \multicolumn{2}{|c|}{$3 \min$} & \multicolumn{3}{|c|}{$5 \mathrm{~min}$} \\
\hline & & $\begin{array}{c}\text { Whiteness } \\
\text { degree }\end{array}$ & $\begin{array}{l}\text { Yellowness } \\
\text { Index }\end{array}$ & $\begin{array}{c}\text { Whiteness } \\
\text { degree }\end{array}$ & $\begin{array}{l}\text { Yellowness } \\
\text { Index }\end{array}$ & $\begin{array}{c}\text { Whiteness } \\
\text { degree }\end{array}$ & $\begin{array}{l}\text { Yellowness } \\
\text { Index }\end{array}$ & Hydrophilicity * (s) \\
\hline \multirow{3}{*}{ 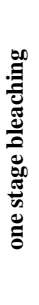 } & $\begin{array}{l}\text { Peroxide bleaching } \\
\text { under acidic conditions } \\
\text { ( } 90 \mathrm{ml} / 1 \mathrm{H} 2 \mathrm{O} 2-\mathrm{pH} 5 \text { ) }\end{array}$ & 60,31 & 15,88 & 61,73 & 16,01 & 63,47 & 14,01 & $17 "$ \\
\hline & $\begin{array}{l}\text { Peroxide bleaching } \\
\text { under alkaline } \\
\text { conditions }(45 \mathrm{ml} / 1 \\
\mathrm{H} 2 \mathrm{O} 2-\mathrm{pH} 9)\end{array}$ & 59,55 & 16,4 & 61,38 & 15,99 & 61,81 & 15,18 & $36 "$ \\
\hline & $\begin{array}{l}\text { TUDO bleaching }(10 \mathrm{~g} / 1 \\
\text { TUDO- } \mathrm{pH} 10)\end{array}$ & 58,82 & 16,08 & 60,91 & 13,98 & 62,2 & 12,62 & $32 "$ \\
\hline \multirow{2}{*}{ 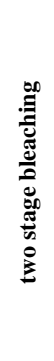 } & $\begin{array}{l}\text { Peroxide bleaching } \\
\text { under acidic conditions } \\
(90 \mathrm{ml} / \mathrm{l} \mathrm{H} 2 \mathrm{O} 2-\mathrm{pH} 5) \\
\text { after TUDO }(10 \mathrm{~g} / 1 \\
\text { TUDO- } \mathrm{pH} 10)\end{array}$ & & & & & 67,21 & 10,46 & 21" \\
\hline & $\begin{array}{l}\text { Peroxide bleaching } \\
\text { under alkaline } \\
\text { conditions }(45 \mathrm{ml} / 1 \\
\mathrm{H} 2 \mathrm{O} 2-\mathrm{pH} 9) \text { after } \\
\text { TUDO (10g/l TUDO- } \\
\text { pH 10) }\end{array}$ & & & & & 65,97 & 11,22 & 25" \\
\hline
\end{tabular}

* Hydrophilicity values of samples treated with microwave for 5 minutes. 
Table 6. Bursting strength values of $100 \%$ milk fiber fabrics

\begin{tabular}{|c|c|c|c|c|}
\hline & $\begin{array}{c}\text { Whiteness } \\
\text { degree (Stensby } \\
\text { value) }\end{array}$ & $\begin{array}{c}\text { Bursting } \\
\text { strength } \\
(\mathbf{k P a}) \\
\end{array}$ & $\begin{array}{l}\text { Weight loss } \\
\quad(\%)\end{array}$ & $\begin{array}{l}\text { Hydrophilicity } \\
\text { (s) }\end{array}$ \\
\hline Control fabric (unbleached) & & 290,2 & & 90 \\
\hline \multicolumn{5}{|l|}{ Conventional bleaching } \\
\hline $\begin{array}{l}\text { Peroxide bleaching under acidic conditions }(65 \mathrm{ml} / 1 \mathrm{H} 2 \mathrm{O} 2-\mathrm{pH} \\
\left.5,60^{\circ} \mathrm{C}-60 \mathrm{~min}\right)\end{array}$ & 63,07 & 269,6 & 12,73 & 38 \\
\hline $\begin{array}{l}\text { Peroxide bleaching under acidic conditions }\left(90 \mathrm{ml} / 1 \mathrm{H}_{2} \mathrm{O}_{2-}-\mathrm{pH}\right. \\
\left.5,60^{\circ} \mathrm{C}-60 \mathrm{~min}\right)\end{array}$ & 65,31 & 253,9 & 14,18 & 26 \\
\hline $\begin{array}{l}\text { Peroxide bleaching under alkaline conditions }\left(45 \mathrm{ml} / 1 \mathrm{H}_{2} \mathrm{O}_{2-}-\mathrm{pH}\right. \\
\left.9,50{ }^{\circ} \mathrm{C}-120 \mathrm{~min}\right)\end{array}$ & 64,44 & 231,7 & 10,93 & 45 \\
\hline $\begin{array}{l}\text { Peroxide bleaching under alkaline conditions }\left(45 \mathrm{ml} / 1 \mathrm{H}_{2} \mathrm{O}_{2}-\right. \\
\left.9,60{ }^{\circ} \mathrm{C}-120 \mathrm{~min}\right)\end{array}$ & 64,89 & 240 & 9,1 & 31 \\
\hline TUDO bleaching (10 g/l TUDO, pH 10-90 $\left.{ }^{\circ} \mathrm{C}-60 \mathrm{~min}\right)$ & 67,22 & 276,5 & 12,23 & 17 \\
\hline \multicolumn{5}{|l|}{ Bleaching with microwave } \\
\hline $\begin{array}{l}\text { Peroxide bleaching under acidic conditions }\left(90 \mathrm{ml} / 1 \mathrm{H}_{2} \mathrm{O}_{2-}\right. \\
5,5 \mathrm{~min})\end{array}$ & 63,47 & 272.3 & 12,45 & 17 \\
\hline $\begin{array}{l}\text { Peroxide bleaching under alkaline conditions }\left(45 \mathrm{ml} / 1 \mathrm{H}_{2} \mathrm{O}_{2-}-\mathrm{pH}\right. \\
9,5 \mathrm{~min})\end{array}$ & 61,81 & 259,6 & 10,35 & 36 \\
\hline TUDO bleaching ( $10 \mathrm{~g} / 1$ TUDO, pH 10, $5 \mathrm{~min})$ & 62,20 & 270,5 & 8,28 & 25 \\
\hline
\end{tabular}

Bursting strength values of samples subjected to bleaching by peroxide with the help of microwave energy are slightly higher than those measured in the classical method (Table 6). This is thought to be due to the fact that the processing time is considerably shorter than the conventional method. Reductive bleaching is the opposite; bursting strength values of bleached samples in the presence of microwave energy with reductive bleaching agents are slightly lower than the conventional method. During the reductive bleaching process with microwave energy, the temperature of the liquor can be reached to boiling temperature within 5 minutes of treatment time, on the contrary in the conventional method; the process is carried out at a constant temperature of $90^{\circ} \mathrm{C}$. Although the process time in microwave bleaching is short, it is thought that the increase in temperature during the process might have slightly increased the strength losses of the samples. In the strength, loss values of milk fiber based knitted fabrics the increase in the weight of milk fiber based knitted fabrics due to the process temperature is effective. As the processing time and temperature increase, the dimensional stability of the milk fiber based fabrics changes, the fabrics shrink and their weights are increased (Figure 9).

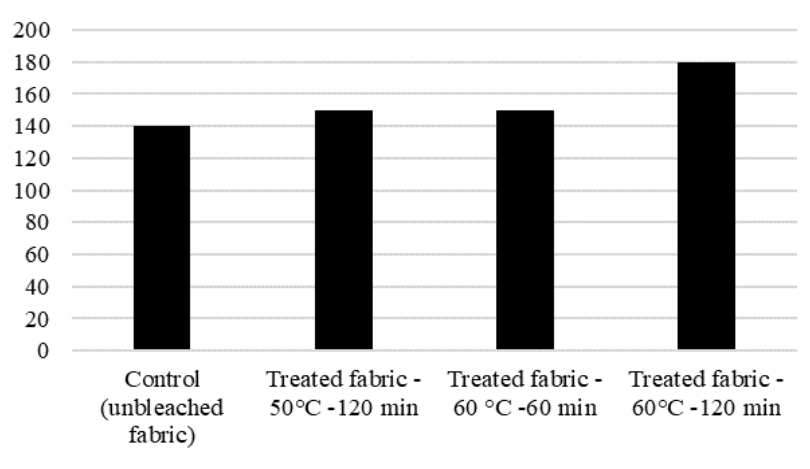

Figure 9. Weight changes of milk fiber based fabrics under different processing conditions

The increase in the thickness of the fabrics also confirms that the fabrics were shrunk (Table 7).

\section{Evaluation of air permeability of casein fabrics}

Figure 10 indicates the air permeability results. The air permeability of all bleached casein fabrics decreased compared to the control fabric. In this case, it is confirmed that, depending on the processing conditions, the fabrics are shrunk, compacted and therefore the air permeability of the fabrics is reduced.

Table 7. Thickness test results of milk fiber based knitted fabrics

\begin{tabular}{l|ccc}
\cline { 3 - 4 } \multicolumn{1}{c|}{} & Fabric thickness (Leipzig Nr.7880) & (micron) \\
\hline Control fabric (unbleached) & & & 4 \\
\hline Peroxide bleaching under acidic conditions & $(90 \mathrm{ml} / 1 \mathrm{H} 2 \mathrm{O} 2-$ & $\left.\mathrm{pH} 5,60{ }^{\circ} \mathrm{C}-60 \mathrm{~min}\right)$ & 4,1 \\
Peroxide bleaching under alkaline conditions & $\left(45 \mathrm{ml} / 1 \mathrm{H} 2 \mathrm{O} 2-\quad \mathrm{pH} 9,60{ }^{\circ} \mathrm{C}-120 \mathrm{~min}\right)$ & 4,2 & 4,8 \\
TUDO bleaching & $\left(10 \mathrm{~g} / 1 \mathrm{TUDO}-\mathrm{pH} 10-90{ }^{\circ} \mathrm{C}-60 \mathrm{~min}\right)$ & 4,8 \\
\hline
\end{tabular}




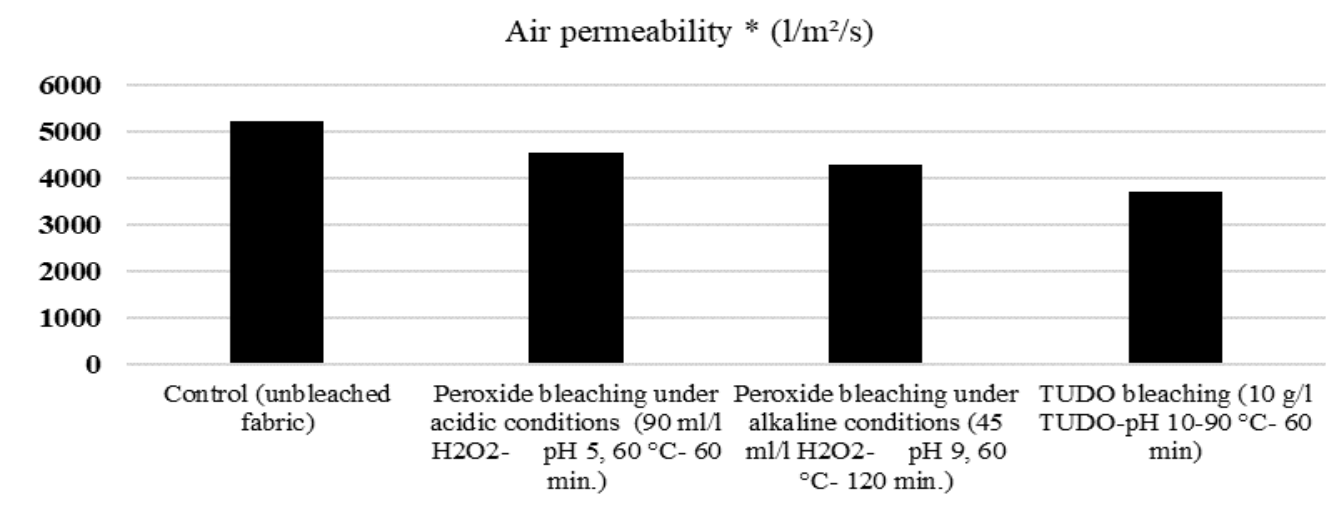

Figure 10. Air permeability test results of milk fiber based knitted fabrics

\section{Evaluation of SEM and FTIR analysis of casein fabrics}

Figure 11 shows SEM images of bleached milk fibers with peroxide and TUDO in acidic and basic media. Strips are observed on the surface of the fibers treated in basic medium.

The absorption peak at $1647 \mathrm{~cm}^{-1}$, represents $\mathrm{C}=\mathrm{O}$ structure in amide I bond which confirms the presence of protein. Peak at $1530 \mathrm{~cm}^{-1}$ represents strong amide II bond which is formed due to N-H bonding of C-N-H group [15].

Amide I $\left(1658 \mathrm{~cm}^{-1}\right)$ and Amide II $\left(1538 \mathrm{~cm}^{-1}\right)$ peaks are characteristic peaks peaks for casein fibers in the FTIR spectrum [2]. FTIR-ATR analysis shows that there is no bulk change in bleached casein fabrics compared to control fabric (Figure 12).

\section{Chemical oxygen demand (COD)}

In order to investigate the environmental impacts of the recipes giving the best whiteness degree, the Chemical Oxygen Demand (COD) measurements of wastewaters were measured by using Closed Reflux, Titrimetric Method and the results are given in Table 8 below.
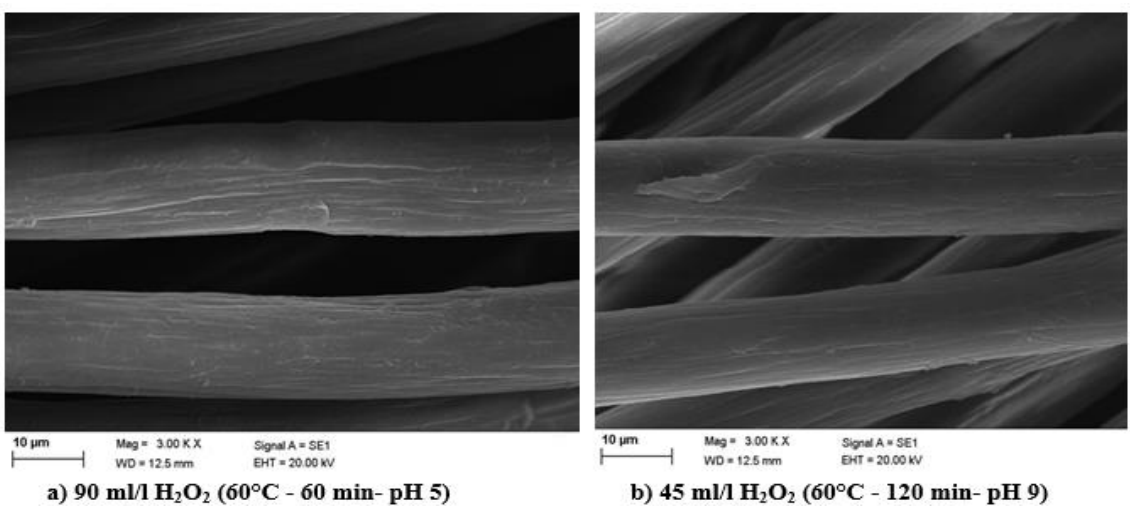

b) $45 \mathrm{ml} / 1 \mathrm{H}_{2} \mathrm{O}_{2}\left(60^{\circ} \mathrm{C}-120 \mathrm{~min}-\mathrm{pH} 9\right)$

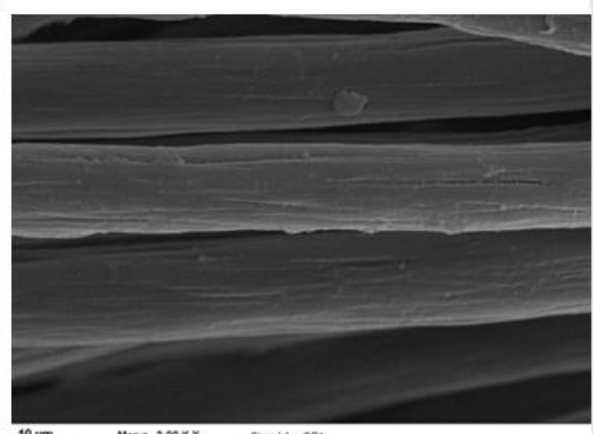

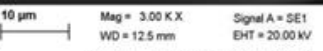

c) $10 \mathrm{~g} / 1$ TUDO $\left(90^{\circ} \mathrm{C}-60 \mathrm{~min}-\mathrm{pH} 10\right)$

Figure 11. SEM images of bleached milk casein fabric samples. a) Peroxide bleaching under acidic conditions, b) Peroxide bleaching under alkaline conditions c) TUDO bleaching 


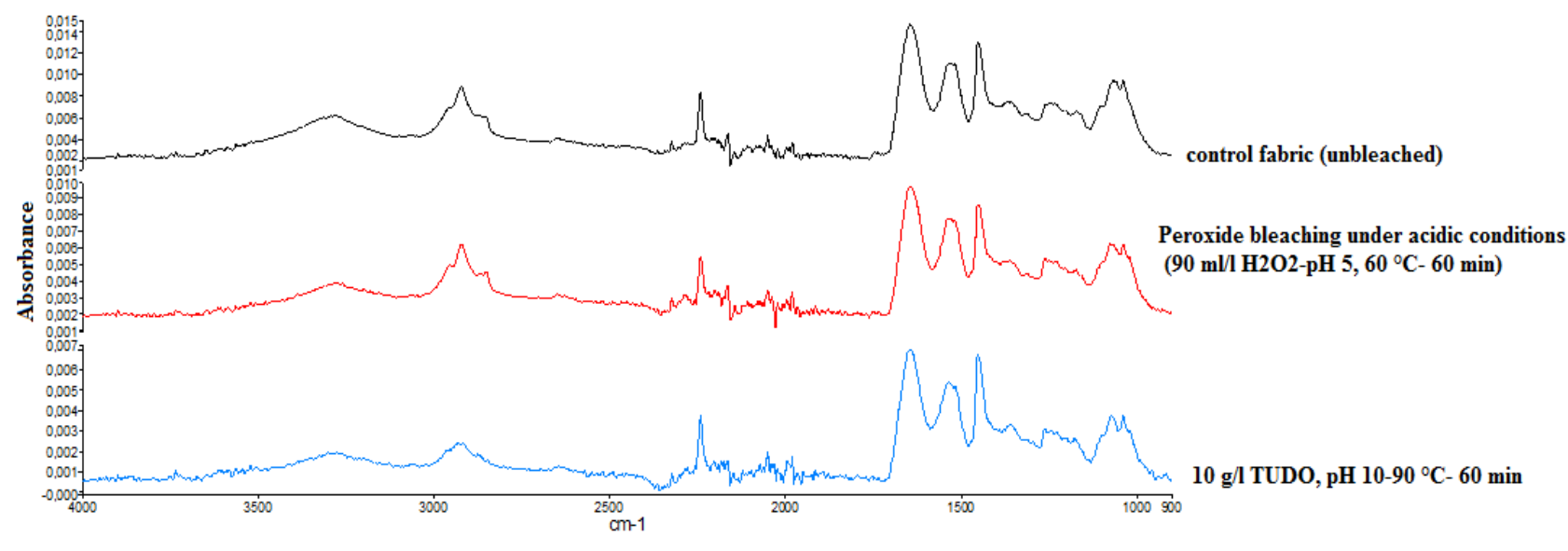

Figure 12. FTIR-ATR Analysis of milk casein fabric samples

Table 8. COD values measured according to Closed Reflux, Titrimetric Method of bleaching liquors of conventional method

\begin{tabular}{lc}
\hline & $\begin{array}{c}\text { Chemical Oxygen } \\
\text { Demand (COD) }\end{array}$ \\
\hline Peroxide bleaching under acidic conditions $\left(90 \mathrm{ml} / 1 \mathrm{H}_{2} \mathrm{O}_{2}-\mathrm{pH} 5, \quad 60{ }^{\circ} \mathrm{C}-60 \mathrm{~min}.\right)$ & $12,55 \mathrm{~g} / 1$ \\
Peroxide bleaching under alkaline conditions $\left(45 \mathrm{ml} / 1 \mathrm{H}_{2} \mathrm{O}_{2}-\mathrm{pH} 9,60{ }^{\circ} \mathrm{C}-120 \mathrm{~min}\right)$ & $6,77 \mathrm{~g} / 1$ \\
TUDO bleaching $\left(10 \mathrm{~g} / \mathrm{l} \mathrm{TUDO}-\mathrm{pH} 10-90{ }^{\circ} \mathrm{C}-60 \mathrm{~min}\right)$ & $1,26 \mathrm{~g} / \mathrm{l}$ \\
\hline
\end{tabular}

The environmental problems of the textile industry are based on the amount of wastewater and the chemical load of these wastewaters, energy consumption and waste air emissions. Environmental problems associated with hydrogen peroxide bleaching result from the use of strong complexing agents (stabilizers) [33]. The COD measurements of the wastewaters were measured by using the Closed Reflux Colorimetric Method to examine the environmental impacts of the recipes giving the best whiteness degree. When COD values were examined; It can be said that the most ecological bleaching method is reductive bleaching because it has the lowest COD value. TUDO, which provides the best whiteness degree with the classical method in this study, stands out with its more ecological feature.

\section{CONCLUSIONS}

Milk fibers, which can be obtained even from the protein of sour milk, provide an comfortable feeling due to the compatibility of the $\mathrm{pH}$ value with the human body, have bright colors due to their good dyeing ability and have ecological properties as well as biodegradable properties which makes the fiber an advantageous choice. In this study, whiteness, yellowness, hydrophilicity and strength properties of milk fiber fabrics were investigated before and after different bleaching processes. According to the process conditions whiteness value measured in 120 minutes at a concentration of $45 \mathrm{ml} / 1 \mathrm{H}_{2} \mathrm{O}_{2}$ at $\mathrm{pH} 9$ at $50^{\circ} \mathrm{C}$ in peroxide bleaching made in alkaline medium is 64,44 Stensby, on the other hand whiteness value measured in
120 minutes at a concentration of $45 \mathrm{ml} / 1 \mathrm{H}_{2} \mathrm{O}_{2}$ at $60^{\circ} \mathrm{C}$ is 64,89 Stensby. Since the measured whiteness values are very close to each other, 50 and $60^{\circ} \mathrm{C}$ have been determined as the optimum temperatures. On the other hand in the bleaching with $\mathrm{H}_{2} \mathrm{O}_{2}$ in acidic environment, the best whiteness levels were determined as 65,31 Stensby at $60^{\circ} \mathrm{C}$ for 60 minutes at a concentration of $90 \mathrm{ml} / \mathrm{l}$ and 63.07 Stensby at $60^{\circ} \mathrm{C}$ for 60 minutes at a concentration of 65 $\mathrm{ml} / \mathrm{l}$.

The loss of strength in milk fiber based fabrics which have been bleached with peroxide in acidic medium is less than the loss in bleaching in basic medium.

Air permeability test results show that air permeability decreases with increasing process temperature and process time of milk fiber based fabric samples. It should be noted that the size stability of the milk fiber fabrics may vary depending on the processing conditions. It is recommended to carefully select process temperature and duration and test the dimension change in milk fibers as well as wool fibers. Microwave treatment has significant adventages for bleaching of fabrics produced from casein fibers as microwave is a clean, environmentally friendly, efficient heating technology.

\section{Acknowledgement}

This work was supported by BAP-PAMUKKALE UNIVERSITY (Project Number 2014 FBE 016). 


\section{REFERENCES}

1. Karmakar SR. 1999. Chemical Technology in The Pre-Treatment Processes of Textiles. Textile Science and Technology 12, Amsterdam, Holland: Elsevier.

2. Rijavec T, Zupin Ž. 2011. Soybean Protein Fibres (SPF). In Dora Krezhova Editor (Ed.) Recent trends for enhancing the diversity and quality of soybean products. IntechOpen. DOI: 10.5772/19614. Retrieved from: https://www.intechopen.com/books/recent-trends-forenhancing-the-diversity-and-quality-of-soybean-products/soybeanprotein-fibres-spf-, pp 501.

3. Shurtleff W, Aoyagi A. 2015. History of soybeans and soyfoods in Southeast Asia (13th century to 2010): Extensively annotated bibliography and sourcebook USA: Soyinfo Center.

4. Yang Y, Reddy N. 2012. Properties and potential medical applications of regenerated casein fibers crosslinked with citric acid. International Journal of Biological Macromolecules 51, 37-44.

5. Traill D. 1951. Some trials by ingenious inquisitive persons: regenerated protein fibers. Journal the Society of Dyers and Colorists 67 (7), 257-270

6. Susich G, Zagieboylo W. 1953. Research and development report: the tensile behavior of some protein fibers. U.S., Deparment of Commerce, U.S.A: The Office of Technical Services.

7. Cook JG. 2001. Handbook of Textile Fibres Vol. II-Man-Made Fibres. England: Woodhead Publishing Limited.

8. Tasnim N. 2019. Eco-friendly manufacturing process of casein fiber with it's sustainable features \& comfortable uses. American Journal of Environmental Engineering 9 (2), 31-35.

9. Domaske A. 2012. Patent WO2012079760 A1 Process for Producing Milk Protein Fibers and Milk Protein Fiber Products Obtained Therefrom. Weltorganisation für geistiges Eigentum Internationales Büro.

10. Bier MC, Kohn S, Stierand A, Grimmelsmann N, Homburg SV, Ehrmann A. 2016, November. Investigation of the casein fibre production in an eco-friendly way. Denkendorf International Textile Conference, Aachen, Dresden. Retrieved from: https://www.researchgate.net/publication/310832654_Investigation_of _the_casein_fibre_production_in_an_eco-friendly_way

11. Chauahn N, Arya N, Sodhi S. 2018. Fiber from milk byproducts - a new dimension. International Journal of Current Microbiology and Applied Sciences 7 (4), 1257-1264.

12. Saluja M. 2010. An introduction to milk fiber- a review. Retrieved from https://www.fibre2fashion.com/industry-article/5279/anintroduction-to-milk-fiber-a-review

13. Sevgisunar HG, Yavas A, Avinc OO. 2015. May. Regenarated protein fiber: casein. In EE. Editor (Petrovic V.), Proceedings of the VII. International Textile Science and Economy Scientific-Professional Conference (162-165). Zrenjanin, Serbia.

14. Lei S, Jianwei C, Meiling Z. 2017. A study of wearabilities of milk protein fiber fabric. Journal of Applied Science and Engineering Innovation 4 (4), 141-143.

15. Rathinamoorthy R. 2017. Moisture management characteristics of knitted casein fabric. Indian Journal of Fibre \& Textile Research 42 , 488-499.

16. Katović D. 2011. Microwaves in textile finishing, Yes or No. Journal of Textile Science \& Engineering. [DOI: 10.4172/21658064.1000e1021]

17. Ghayempour S, Mortazavi SM. 2015. Microwave curing for applying polymeric nanocapsules containing essential oils on cotton fabric to produce antimicrobial and fragrant textiles. Cellulose 22(6), 40654075 .

18. Budimir A, Vukusic SB, Flincec SG. 2012. Study of antimicrobial properties of cotton medical textiles treated with citric acid and dried/cured by microwaves. Cellulose 19(1), 289-296.
19. Moustafa MG, Fouda A, Shafei E, Sharaf S, Hebeish A. 2009. Microwave curing for producing cotton fabrics with easy care and antibacterial properties. Carbohydrate Polymers 77, 651-655.

20. Purwar R, Joshi M. 2009. Effect of microwave curing on easy care finishing of cotton using glyoxal/glycol. AATCC Review 9(7), 38-42.

21. Katovic D, Vukusic SB, Hrabar S, Bartolic J. 2005, October. Microwaves in chemical finishing of textiles. Proceedings of the Applied Electromagnetics and Communications (ICECom), Dubrovnik, Croatia.

22. Yükseloğlu M, Sökmen N. 2012, October. Hydrogen peroxıde/microwave assısted bleachıng of linen fabrics. Proceedings of the $6^{\text {th }}$ International Textile, Clothing \& Design Conference, Dubrovnik, Croatia.

23. Ozerdem A, Tarakçıoğlu I, Ozgüney AT. 2008. The use of microwave energy for the fixating of reactive printed cotton fabrics. Tekstil ve Konfeksiyon 4, 289-296.

24. Yavas A, Avinc O, Gedik G. 2017. Ultrasound and microwave aided natural dyeing of nettle biofibre (Urtica dioica L.) with Madder (Rubia tinctorum L.). Fibres \& Textiles in Eastern Europe 25, 4(124), 111 120.

25. Yavas A, Kalayci E, Avinc O, Arik B, Çalışkan A, Börekci BE, Haciali A. 2017, March. Water-oil repellent treatment of viscose fabric with microwave irradiation. In E.E Editor (Sato T.), Proceedings of the Asia and Africa Science Platform Program Establishment of Collaboration Research for Neo-Fiber Technology in Asia and Africa, Annual Report Meeting for 'Neo-Fiber Technology' Project 20162017 Seminar Series 10, (104-105). Kyoto, Japan.

26. Yavas A, Kalayci E, Avinc O, Aras G. 2017, March. Microwave energy fixation for discharge printing on cotton fabic. In E.E Editor (Çınar Ö.) Internatıonal Conference on Engineering Technology and Innovation (ICETI), (77). Sarajevo, Bosnia and Herzegovina.

27. Kalaycı E, Yavas A, Avinc O, Bektas M. 2018, October. Dyeability of soybean fibers with acid dyes under microwave conditions, In E.E Editor (Yücehan T., Sarau U.), Proceedings of the II. International Scientific and Vocational Studies Congress (BILMES 2018), (357). Nevşehir, Turkey.

28. Kalayc1 E, Yavas A, Avinc O, Tugce T. 2019, May. Dyeing performance comparıson of soybean fibers with direct dyes with conventional and microwave technologies. In E.E Editor (Petrovic V.), Proceedings of the Textile Science and Economy X (36-43). Zrenjanin, Serbia.

29. Xue Z. 2018. Effect of Microwave irradiation on the physical properties and structures of cotton fabric. Journal of Engineered Fibers and Fabric 13 (2), 1-6.

30. Abou El-Kheir A, Haggag K, Mowafi SI, El-Sayed H. 2015. Microwave-assisted bleaching of wool fabrics. Journal of Natural Fibers 12(2), 97-107.

31. Aniş P. 2005. Tekstil Ön Terbiyesi. Bursa: Alfa Akademi Basım Yayım Dağıtım Ltd. Şti.

32. Bechtold T, Pham T. 2019. Textile Chemistry. Berlin/Boston: Walter de Gruyter $\mathrm{GmbH}$.

33. Schönberger H, Schaefer T. 2003. March. Best available techniques in textile industry (Research Report 20094 329). Berlin: Federal Environmental Agency (Umweltbundesamt). 
